\title{
Efek Mediasi Keterikatan Karyawan pada Pengaruh Keadilan Distributif dan Prosedural Terhadap Keinginan Berpindah
}

\author{
Edalmen dan Patricia Fiona Ngadiman \\ Fakultas Ekonomi dan Bisnis, Universitas Tarumanagara, Jakarta \\ Email:edalmen@fe.untar.ac.id
}

\begin{abstract}
This study aims to determine the effect of distributive justice and procedural justice on turnover intention with employee engagement as a mediating variable at PT. XYZ The sample used was 83 respondents with a sample selection method using saturated sampling techniques. The study was conducted quantitatively and used a questionnaire to collect data. The results of this study concluded that distributive justice and procedural justice had a positive effect on employee engagement. Distributive justice has a negative effect on turnover intention, but the effect of procedural justice on turnover intention is not significant. Employee engagement acts as a partial mediation in distributive justice relations to turnover intention and acts as a full mediator on the influence of procedural justice on turnover intention. The next finding is that employee engagement has a negative influence on the desire to.
\end{abstract}

Keywords: distributive justice, procedural justice, employee engagement, turnover intention.

\begin{abstract}
Abstrak: Penelitian ini bertujuan untuk mengetahui pengaruh keadilan distributif dan keadilan prosedural terhadap keinginan berpindah dengan keterikatan karyawan sebagai variabel mediasi pada PT. XYZ. Sampel yang digunakan berjumlah 83 responden dengan metode pemilihan sampel menggunakan teknik sampling jenuh. Penelitian dilakukan secara kuantitatif dan menggunakan kuesioner untuk mengumpulkan data. Hasil penelitian ini menyimpulkan bahwa keadilan distributif dan keadilan prosedural berpengaruh positif terhadap keterikatan karyawan. Keadilan distributif berpengaruh negatif terhadap keinginan berpindah, tetapi pengaruh keadilan prosedural terhadap keinginan berpindah tidak signifikan. Keterikatan karyawan berperan sebagai mediasi secara parsial pada hubungan keadilan distributif terhadap keinginan berpindah dan secara penuh memediasi pengaruh keadilan prosedural terhadap keinginan berpindah. Hasil temuan selanjutnya adalah keterikatan karyawan mempunyai pengaruh negatif terhadap keinginan berpindah.
\end{abstract}

Kata kunci: keadilan distributif, keadilan prosedural, keterikatan karyawan, keinginan berpindah.

\section{LATAR BELAKANG}

Salah satu permasalahan belakangan ini yang banyak menimbulkan keresahan perusahaan-perusahaan adalah tentang keinginan berpindah karyawan (turnover intention). Para karyawan yang berpotensi terhadap kinerja perusahaannya banyak yang mengundurkan diri dan mencari perusahaan lain. Perusahaan membutuhkan para karyawan 
yang potensial dalam bidangnya untuk membangun perkembangan perusahaan. Namun sayangnya, tingginya angka para karyawan yang pindah dari perusahaan tersebut membuat perusahaan kehilangan para karyawaan terbaiknya. Terdapat sejumlah alasan pegawai memilih pindah pekerjaan di perusahaan lain, alasan yang paling banyak yaitu karena kurangnya memiliki kesempatan berkarir dan berkembang.

(Saeka dan Suana, 2016) menyatakan bahwa sumber daya manusia berperan penting dalam suatu perusahaan, tanpa didukung dengan sumber daya manusia yang baik maka perusahaan akan menghadapi masalah dalam pencapaian tujuannya. Fenomena keinginan berpindah karyawan ini menjadi masalah bagi perusahaan ketika karyawan berprestasi tinggilah yang keluar perusahaan. (Dharma, 2013) mendefinisikan keiginan berpindah sebagai kecenderungan sikap yang dimiliki oleh karyawan untuk mencari pekerjaan baru ditempat lain atau juga adanya rencana untuk meninggalkan perusahaan dalam beberapa bulan atau tahun yang akan datang namun tidak bisa ditentukan tanggal yang tetap.

Jika keinginan berpindah diabaikan akan dapat menjadi salah satu masalah di kemudian hari sehingga harus diperhatikan karena dapat mempengaruhi kondisi suatu perusahaan. Keinginan berpindah memiliki konsekuensi kerugian biaya yang signifikan untuk setiap perusahaan dan juga akan berdampak pada kerugian perusahaan seperti pengeluaran biaya untuk perekrutan dan pelatihan karyawan baru (Bothma dan Roodth, 2012). Hal tersebut akan sangat serius jika keinginan berpindah dalam sebuah perusahaan tinggi maka akan menimbulkan beberapa efek negatif dan merugikan bagi perusahaan (Kardiman dan Indriana, 2012). Beberapa diantaranya dapat menciptakan ketidakstabilan terhadap kondisi para tenaga kerja, penurunan produktivitas karyawan, terciptanya suasana kerja yang tidak kondusif dan juga akan berdampak pada peningkatan biaya sumber daya manusia yang akan mendatang. Sebaliknya jika keiginan berpindah rendah dapat memperkecil perputaran karyawan serta biaya-biaya yang dikeluarkan perusahaan (Dewi dan Wibawa, 2016). Perusahaan tidak perlu lagi merekrut karyawan baru untuk menggantikan posisi karyawan yang telah berhenti, sehinga perusahaan tidak perlu mengeluarkan biaya ekstra untuk menggantikan karyawan tersebut

Efek negatif yang akan merugikan perusahaan adalah terdapat peningkatan biayabiaya tertentu khususnya dalam hal perekrutan sampai pelatihan calon karyawan baru agar kekosongan dapat terisi dan kegiatan produksi dapat berjalan normal. Biaya tersebut mencakup biaya yang dibutuhkan mulai dari merekrut karyawan baru, screening, interview, ada juga biaya ekstra untuk pelatihan karyawan baru dan juga termasuk biaya iklan lowongan kerja. Namun, jika perusahaan mengabaikan kekosongan tersebut maka akan berdampak langsung kepada karyawannya. Bertambahnya beban kerja dan faktor-faktor lain dapat menimbulkan ketidaknyamanan bagi karyawan sehingga mengganggu kinerjanya pada perusahaan, jika hal tersebut terjadi secara terus menerus maka keinginan karyawan untuk berpindah pun semakin kuat.

Tingginya keinginan berpindah pada perusahaan juga akan berdampak negatif bagi moral pegawai yang masih bekerja diperusahaan tersebut. Semakin banyak karyawan yang keluar, maka semakin membuat karyawan yang tersisa di perusahaan terebut resah, tak bersemangat dan mendorong niat untuk ikut mencari peluang yang lebih baik di luar sana dan akhirnya meningkatnya lagi keinginan berpindah. Semangat karyawan yang menurun ini akan dapat mempengaruhi hingga ke kultur perusahaan, yang pada akhirnya menyulitkan perusahaan untuk menarik talenta-talenta yang baik. Perusahaan akan kehilangan waktu yang dapat di pakai untuk hal-hal produktivitas. 
(Harhara et al., 2015) menyatakan perusahaan yang tidak memiliki sistem penilaian berdasarkan keadilan memiliki kemungkinan akan menghadapi masalah keinginan berpindah karyawan yang lebih tinggi. Menurut (Lee et al., 2017) proses pengambilan keputusan dapat sangat berpengaruh terhadap penerimaan mengenai hasil suatu keputusan. Oleh karena itu, ada kalanya seseorang tidak setuju dengan hasil suatu keputusan tetapi dapat menerima keputusan tersebut karena proses pengambilan keputusan yang dilakukan dengan adil. Dengan demikian dapat disimpulkan bahwa keadilan distributif (distributive justice) dan keadilan prosedural (procedural justice) menjadi hal yang sangat penting diperhatikan oleh karyawan.

Hasil penelitian (Al-Shbiel et al., 2018), (Sadia, 2018), (Raza et al., 2017) (Özer et al., 2017) menunjukkan bahwa keadilan distributif berpengaruh negatif signifikan terhadap keinginan berpindah. Artinya keinginan berpindah bisa ditekan dengan semakin membaiknya keadilan distributif dan keadilan prosedural. Hasil penelitian itu juga menjelaskan bahwa dalam kaitannya terhadap keinginan berpindah, faktor keadilan akan terlebih dahulu membentuk keterikatan karyawan (employee engagement). Namun hasil yang berbeda dilaporkan oleh (Court et al., 2018) yang menemukan bahwa keadilan distributif dan keadilan prosedural tidak berpengaruh signifikan terhadap keinginan berpindah. Hasil penelitian dari (Mohd et al., 2013) juga menyimpulkan bahwa keadilan prosedural tidak berdampak signifikan terhadap keinginan berpindah.

(Robbins dan Judge, 2015) mengutarakan bahwa keadilan distributif memusatkan perhatian pada keadilan atas hasil yang diterima, misalnya gaji dan pengakuan, yang diterima oleh para pekerja. Para karyawann cenderung untuk menggangap hasil mereka paling adil ketika mereka didistribusikan secara adil oleh perusahaan. Keadilan distributif dalam perusahaan saat ini memfokuskan pada persepsi seseorang terhadap adil tidaknya dengan hasil yang mereka terima (Tjahjono et al., 2014). Prinsip dasar keadilan distributif terletak pada rasio atau perbandingan antara hasil yang diperoleh seseorang dengan hasil yang diperoleh dengan karyawan lain. Keadilan distributif mengacu pada konsep dasar persamaan atau equity.

(Calton and Cattaneo, 2014) berpendapat bahwah keadilan prosedural adalah keadilan yang berfokus pada proses yang digunakan untuk membuat keputusan. Ketika karyawan menganggap keadilan prosedural tinggi, maka karyawan akan lebih termotivasi untuk berpartisipasi dalan kegiatan, mengikuti aturan, dan menganggap hasil yang relavan adalah adil. Tetapi jika para pekerja merasakan kurangnya keadilan prosedural, karyawan akan cenderung menarik diri dari kesempatan untuk berpartisipasi, kurang memperhatikan aturan dan kebijakan pada perusahaan, dan menganggap hasil yang relavan adalah tidak adil.

Menurut (Schaufeli and Bakker, 2004) keterikatan karyawan mengacu pada hubungan antara karyawan dengan pekerjaannya. Karyawan yang memiliki tingkat keterikatan tinggi tentunya bisa muncul karena adanya persepsi adil dari perusahaan terhadap karyawan dan apabila karyawan sudah memiliki tingkat keterikatan yang tinggi, baru dapat mempengaruhi minat keluar karyawan. (Selfiana, 2016) menyatakan keterikatan karyawan merupakan sebuah bentuk keterlibatan atau kerikatan pada karyawan dengan perusahaan yang membuat para karyawan tersebut memiliki komitmen kuat terhadap perusahaan. Karyawan yang mempunyai tingkat keterikatan yang tinggi akan memiliki keterikatan emosi yang tinggi terhadap organisasi sehingga akan berpengaruh dalam menyelesaikan pekerjaan dan cenderung memiliki kualitas kerja sesuai dengan harapan (Cendani dan Tjahjaningsih, 2015). 
Hasil Penelitian dari (Hongwei He et al., 2013) (Özer et al., 2017), (Al-Shbiel et al., 2018), menunjukkan bahwa keadilan distributif dan keadilan prosedural memiliki pengaruh positif terhadap keterikatan karyawan. Adapun (Manish dan Musarrat, 2017) menemukan bahwa keterikatan karyawan mempunyai pengaruh negatif signifikan terhadap keinginan berpindah. Hasil penelitian ini sama seperti yang dilaporkan oleh (Agoi, 2015) dan (Meydy, 2018) yang menyimpulkan bahwa keterikatan karyawan juga mempunyai pengaruh negatif signifikan terhadap keinginan berpindah.

PT. XYZ adalah sebuah suatu perusahaan yang beregerak di bidang konstruksi dan pemasok yang,berdiri sejak tahun 2015. Dengan jumlah karyawan sebanyak 83 orang saat ini perusahaan menghadapi masalah banyaknya karyawan yang mengajukan diri untuk keluar dari perusahaan. Oleh karena itu, maka penelitian ini bertujuan untuk mengetahui hal-hal yang menyebabkan tingginya minat keluar dari karyawan. Fokus penelitian ini adalah faktor yang muncul dari aspek keadilan distributif dan keadilan prosedural dalam perusahaan yang di mediasi oleh keterikatan karyawan.

\section{KAJIAN TEORI}

Keadilan distributif adalah keadilan yang dapat dinilai karyawan berdasarkan perolehan hasil (outcome) yang mereka terima dari perusahaan (Raza, et al., 2017). Keadilan distributif dapat diartikan sebagai persepsi para pegawai di suatu organisasi yang menganggap bahwa semua yang didapatkannya selama bekerja di organisasi tersebut adalah wajar sesuai imbalan atau kompensasi yang harus diperolehnya.. Keadilan distributif dikonseptualisasikan sebagai keadilan yang terkait dengan hasil yang didapat karyawan atas jasa yang diperbuatnya. Hasil yang didapat karyawan berbentuk berwujud (reward) atau tidak terwujud (pujian) (Colquitt et al., 2015). Persepsi keadilan distributif dapat diterapkan pada perusahaan dengan adanya outcome yang seimbang dengan input..

(Tjahjono et al., 2014) menyatakan bahwa keadilan distributif dapat dicapai ketika penerimaan dan masukan atau inputs dan outcomes sebanding dengan yang diperoleh rekan kerja. Jika perbandingan atau proporsinya lebih besar atau lebih kecil, maka karyawan menilai hal tersebut tidak adil. Referensi pembandingnya adalah karyawan lain yang dipersepsikan memiliki posisi yang sama (Özer et al., 2017). (Robbins dan Judge, 2015) mengutarakan bahwa keadilan distributif memusatkan perhatian pada keadilan atas hasil yang diterima, misalnya gaji dan pengakuan, yang diterima oleh para pekerja. Para karyawan cenderung untuk menggangap hasil mereka paling adil ketika mereka didistribusikan secara adil oleh perusahaan.

(Greenberg dan Baron, 2007) menyatakan bahwa keadilan distributif dapat didefinisikan sebagai sebuah bentuk keadilan yang berfokus pada keyakinan karyawan bahwa mereka telah menerima jumlah imbalan yang sesuai serta mendapatkan penghargaan. Imbalan atau kompensasi merupakan faktor penting yang mempengaruhi bagaimana dan mengapa karyawan bersedia bekerja pada suatu perusahaan tersebut dan bukan pada perusahaan yang lainnya.

Keadilan prosedural merujuk pada keadilan yang diterima dari prosedur yang digunakan untuk membuat keputusan-keputusan (Chi dan Han, 2008). Keadilan prosedural akan dirasakan seseorang melalui proses dan prosedur yang diaplikasikan dalam pengambilan keputusan (Kreitner dan Kinicki, 2013). (Calton dan Cattaneo, 2014) menyatakan bahwa keadilan prosedural didefinisikan sebagai keadilan yang berfokus pada 
proses yang digunakan untuk membuat keputusan. Keadilan prosedural merupakan keadilan organisasi yang terkait dengan prosedur pengambilan keputusan oleh perusahaan yang ditujukan pada karyawan perusahaan (Alotaibi, 2001).

Keadilan prosedural berkaitan dengan pembuatan dan implementasi keputusan yang mengacu pada proses yang adil. Karyawan akan merasa setuju jika prosedur yang diterapkan, memperlakukan mereka dengan kepedulian dan martabat, membuat prosedur itu mudah diterima bahkan jika ada karyawan yang tidak menyukai hasil dari prosedur tersebut (She dan Santosa, 2012). Keadilan prosedural mengacu kepada perasaan adil dari suatu proses pengambilan keputusan yang dibuat, termasuk pemberian kesempatan karyawan dalam proses pengambilan keputusan, menyampaikan ide, atau informasi yang akurat yang digunakan untuk pengambilan keputusan (Chi dan Han, 2008). (Budiarto dan Wardani, 2005) mengungkapkan bahwa keadilan prosedural berbeda dengan proses psikologis individu, dimana individu cenderung melakukan evaluasi terhadap keadilan akan prosedurprosedur yang ada. Para karyawan ingin mengetahui keputusan apa yang diambil dan bagaimana proses keputusan dibuat. Dalam suatu perusahaan, jika karyawan merasa dalam evaluasi pembuatan keadilan prosedur tidak sesuai aturan maka karyawan mempersepsinya tidak ada keadilan. Para manajer dianggap melakukan diskriminasi dalam keputusan mereka (Lewis, 2013).

Keterikatan karyawan merupakan antusiasme karyawan dalam bekerja yang terjadi karena karyawan mengarahkan energinya untuk bekerja yang selaras dengan prioritas strategi perusahaan. Rasa antusiasme ini terbentuk karena adanya keterikatan sehingga berpotensi untuk menampilkan perilaku yang loyal. Perilaku yang loyal memberikan dampak positif bagi perusahaan (Dematria dan Hendriady, 2017). Karyawan yang mempunyai tingkat keterikatan tinggi akan memiliki keterikatan emosi yang tinggi terhadap organisasi sehingga akan berpengaruh dalam menyelesaikan pekerjaan dan cenderung memiliki kualitas kerja sesuai dengan harapan (Cendani dan Tjahjaningsih, 2015). Selanjutnya menurut (Mustika dan Rahardjo, 2017) keterikatan karyawan merupakan hubungan yang kuat antara karyawan dengan pekerjaan, dan dengan semua karyawan yang ada. Karyawan mampu menemukan makna di dalam pekerjaan, bangga dengan apa yang dilakukan dan percaya bahwa perusahaan akan menghargai apa yang dilakukan untuk menunjang keberhasilan perusahaan.

Selanjutnya (Schaufeli and Bakker, 2004) menyatakan bahwa keterikatan karyawan mengacu pada pikiran yang ditandai dengan persepsi optimistis untuk memenuhi tugas. Sedangkan menurut (Harter et al., 2002) keterikatan karyawan merupakan suatu keterlibatan, kepuasan, dan antusiasme individu dalam melakukan pekerjaan. Menurut (Selfiana, 2016) keterikatan karyawan meupakan sebuah bentuk keterlibatan atau kerikatan pada karyawan dengan organisasi atau perusahaan yang membuat para karyawan tersebut memiliki komitmen kuat terhadap perusahaan. Karyawan yang mempunyai ikatan kuat dengan perusahaan serta merasa nyaman dan senang dengan hal-hal yang ada di lingkungan kerjanya maupun tanggung jawab tugas yang dimiliki, maka karyawan dapat meningkatkan kinerjanya guna mendukung keberhasilan perusahaan.

Keterikatan karyawan dapat diartikan sebagai suatu rasa keterikatan secara emosional dengan pekerjaan dan perusahaan, termotivasi dan mampu memberikan kemampuan terbaik mereka untuk membantu suksesnya dari serangkaian manfaat bagi perusahaan dan karyawan (MacLeod and Clarke, 2009). Ketika rasa keterikatan dengan perusahaan yang dimiliki oleh karyawan semakin tinggi, maka akan menghasilkan suatu perilaku umum 
positif, salah satunya keputusan karyawan untuk tetap tinggal atau terus bekerja di organisasi tersebut meskipun terdapat peluang kerja di tempat lainnya.

Keinginan berpindah dapat diartikan sebagai niat karyawan untuk berpindah dari suatu perusahaaan atau keluar dari perusahaan, baik dalam bentuk pemberhentian atau pengunduran diri (Rarasanti dan Suana, 2016). (Fong dan Mahfar, 2013) menyatakan keinginan berpindah sebagai kemungkinan bahwa seorang karyawan akan mengundurkan diri dari pekerjaanya saat ini dalam jangka waktu tertentu. (Vera, 2014) mengungkapkan bahwa keinginan berpindah merupakan perasaan yang timbul dari individu yaitu niat untuk berhenti dari pekerjaanya secara sukarela menurut pilihannya sendiri.

(Ronald dan Meliana, 2014) mendefinisikan keinginan berpindah adalah kecenderungan individu untuk meninggalkan perusahaan dengan berbagai alasan dan diantaranya berkeinginan untuk mendapatkan pekerjaan yang lebih baik. Perusahaan tidak perlu lagi merekrut karyawan baru untuk menggantikan posisi karyawan yang telah berhenti, sehinga perusahaan tidak perlu mengeluarkan biaya ekstra untuk menggantikan karyawan tersebut. Pada dasarnya sikap individu yang mempunyai keinginan untuk keluar dari suatu perusahaan adalah hal yang umum. Keinginan berpindah yang terjadi dalam perusahaan mengarah pada kenyataan akhir yang berupa keluarnya karyawan pada periode tertentu (Murfat, 2018).

Persepsi keadilan distributif dan keadilan prosedural mempengaruhi kepuasan individu dengan berbagai pekerjaan yang berhubungan dengan hasil seperti gaji, tugas kerja, pengakuan, dan kesempatan untuk kemajuan. Oleh sebab itu, karyawan akan sangat sensitif dengan keadilan yang berkaitan dengan nasib mereka di perusahaan tersebut. Semakin baik kesempatan dan peluang mereka untuk mendapatkan gaji yang lebih tinggi, ataupun posisi lebih baik, maka akan semakin kerasan karyawan terhadap perusahaan. Selanjutnya karyawan akan merasa semakin merasa memiliki ikatan khusus bahkan keterikatan dengan perusahaan. Hal ini akan dapat mempengaruhi minat karyawan untuk tetap bertahan dan tidak keluar dari perusahaan. Berdasarkan kerangka pemikiran ini dapat digambarkan model penelitiannya adalah sebagai berikut :

Gambar 1. Model Penelitian

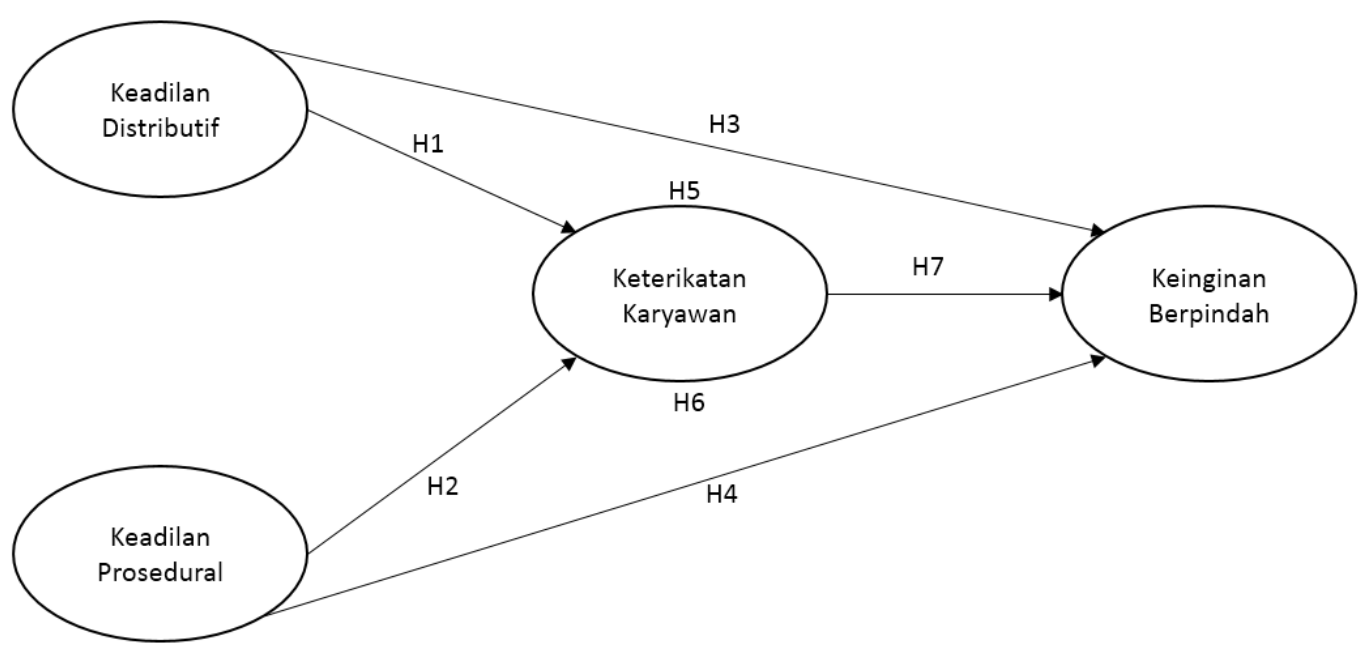


Berdasarkan model penelitian diatas maka dapat dirumuskan hipotesis penelitian sebagai berikut:

H1: Keadilan distributif berpengaruh positif terhadap keterikatan karyawan.

H2: Keadilan prosedural berpengaruh positif terhadap keterikatan karyawan.

H3: Keadilan distributif berpengaruh negatif terhadap keinginan berpindah.

H4: Keadilan prosedural berpengaruh negatif terhadap keinginan berpindah.

H5: Keadilan distributif berpengaruh negatif terhadap keinginan berpindah melalui mediasi keterikatan karyawan.

H6: Keadilan prosedural berpengaruh negatif terhadap keinginan berpindah melalui mediasi keterikatan karyawan.

H7: Keterikatan karyawan berpengaruh negatif terhadap keinginan berpindah.

\section{METODOLOGI}

Desain penelitian berguna sebagai gambaran mengenai bagaimana penelitian tersebut dilakukan secara sistematis. Penelitian ini menggunakan desain penelitian kasual karena menguji hubungan sebab akibat antara keadilan distributif dan keadilan prosedural terhadap keinginan berpindah dengan keterikatan karyawan sebagai variabel mediasi yang dikaji menggunakan pendekatan penelitian kuanitatif (Sekaran dan Bougie, 2016). Penelitian ini mengumpulkan data menggunakan kuesioner yang didukung oleh beberapa acuan teori dari para ahli dan menggunakan metode desktiptif dengan desain cross-sectional. Populasi pada penelitian ini adalah seluruh karyawan yang bekerja di PT. XYZ sebanyak 83 orang. Dengan teknik sampling jenuh maka seluruh populasi dijadikan sampel. Data dianalisis menggunakan PLS-SEM dimana data diolah dengan program software Smart PLS 3.0.

Pengujian pertama akan dilakukan pada outer model analisys untuk menguji validitas dan reliabilitas data. Uji validitas dilihat dari besar kecilnya nilai factor loading convergent validity pada setiap variabel laten dengan indikator-indikatornya masing masing. Nilai yang diarapkan $>0.7$. Selanjutnya, dilakukan pula uji reliabilitas yang digunakan untuk menguji nilai reliabilitas dari setiap blok indikator yang mengukur sebuah konstruk, dimana konstruk akan dinyatakan reliabel jika nilai cronbach's alpha> 0.6 dan composite reliability $>0,7$ (Hussein, 2015).

Pengolahan data selanjutnya dilakukan pada inner model analysis. Analisis ini dapat dilakukan apabila seluruh variabel dan indikator yang digunakan dalam penelitian ini sudah valid dan reliable. Tujuan dari analisa inner model ini untuk menguji hipotesis yang telah ditentukan diawal apakah diterima atau ditolak. Sebelum pengujian hipotesis, terlebih dahulu akan dilakukan pengujian besarnya pengaruh variabel independen terhadap variabel dependen dengan melihat nilai $\mathrm{R}$-square $\left(\mathrm{R}^{2}\right)$. Nilai $\mathrm{R}^{2}$ berkisar anatara 0 hingga 1 , dimana jika $\mathrm{R}^{2}$ adalah 1 merepresentasikan akurasi prediktif yang sempurna (Hair et al., 2011). Predictive Relevance digunakan untuk menjelaskan relevansi dari inner model dalam penelitian.

Konstruk endogen dinyatakan relevan untuk memprediksi model penelitian apabila memiliki nilai $\mathrm{Q}^{2}$ lebih dari 0 . Goodness of Fit $(\mathrm{GoF})$ digunakan untuk menggambarkan tingkat kelayakan model secara keseluruhan. Nilai GoF diperoleh dari akar kuadrat dari average communalities index dikalikan dengan nilai rata-rata $\mathrm{R}^{2}$ model dan terbentang dari angka $0-1$ dengan interpretasi nilai yang dibagi menjadi tiga, nilai $\mathrm{GoF}=0,1$ (kecil), $\mathrm{GoF}=0,25$ (sedang) dan $\mathrm{GoF}=0,38$ (besar). Pengujian hipotesis, untuk melihat pengaruh 
yang terjadi lihat (positif/ negatif) dari angka coefficient yang dihasilkan, dan menggunakan nilain $t$-statistics $>1,96$ (agar hipotesis tidak ditolak) dan $p$-values $<0,05$ (hipotesis signifikan) (Ghozali dan Latan, 2015).

Untuk melihat efek mediasi akan terdapat beberapa kemungkinan yang akan terjadi jika mediasi ditambahkan (Garson, 2016), yaitu: Saat variabel mediasi ditambahkan dan nilai indirect effect turun sampai 0 maka variabel mediasi memiliki efek full control. Saat variabel mediasi ditambahkan dan nilai indirect effect hanya turun sebagian menuju 0 maka variabel mediasi memiliki efek partial control. Saat variabel mediasi ditambahkan dan nilai indirect effect tidak berubah maka variabel mediasi tersebut no effect. Saat variabel mediasi ditambahkan dan nilai indirect effect meningkat dibandingkan direct effect maka dinamakan suppression.

Operasionalisasi variabel dilakukan dengan mengacu pada dimensi perilaku, aspek, atau properti yang ditunjukkan oleh definisi konseptual variabel, yang kemudian diterjemahkan ke dalam elemen yang dapat diobservasi dan diukur untuk mengembangkan indeks pengukuran konsep (Sekaran dan Bougie, 2016) Operasionalisasi variabel penting karena akan memudahkan untuk mengukur variabel tersebut baik untuk variabel dependen maupun variabel independen. Tabel 1, tabel 2, tabel 3 dan tabel 4 dibawah ini menjelaskan variabel dan indikator yang digunakan dan akan diolah datanya dalam penelitian ini.

Tabel 1. Operasionalisasi Variabel Keadilan Prosedural

\begin{tabular}{|c|c|c|c|c|}
\hline Variable & Definisi & Indikator & Kode & Skala \\
\hline \multirow[t]{5}{*}{$\begin{array}{l}\text { Keadilan } \\
\text { prosedural }\end{array}$} & \multirow{5}{*}{$\begin{array}{l}\text { Keadilan Prosedural } \\
\text { yaitu proses } \\
\text { pengambilan } \\
\text { keputusan yang akan } \\
\text { mempengaruhi } \\
\text { persepsi seseorang } \\
\text { mengenai hasil suatu } \\
\text { keputusan, walaupun } \\
\text { pilihan seseorang } \\
\text { mengenai hasil suatu } \\
\text { keputusan, walaupun } \\
\text { pilihannya } \\
\text { berlawanan dengan } \\
\text { hasil keputusan yang } \\
\text { telah diputuskan, } \\
\text { namun dengan } \\
\text { adanya procedural } \\
\text { justicer karyawan } \\
\text { akan dapat menerima } \\
\text { keputusan tersebut }\end{array}$} & $\begin{array}{l}\text { Memiliki kebijakan } \\
\text { kesetaraan ketenagakerjaan } \\
\text { yang adil }\end{array}$ & PJ1 & \multirow[t]{5}{*}{ Ordinal } \\
\hline & & $\begin{array}{l}\text { Memastikan karyawan } \\
\text { memiliki akses yang sama } \\
\text { ke program kesehatan. }\end{array}$ & $\mathrm{PJ} 2$ & \\
\hline & & $\begin{array}{l}\text { Menerapkan kebijakan dan } \\
\text { prosedur disiplin secara } \\
\text { konsisten. }\end{array}$ & $\mathrm{PJ} 3$ & \\
\hline & & $\begin{array}{l}\text { Gaji yang adil untuk } \\
\text { karyawan di pekerjaan dan } \\
\text { posisi yang sama. }\end{array}$ & $\mathrm{PJ} 4$ & \\
\hline & & $\begin{array}{l}\text { Kebijakan tunjangan } \\
\text { karyawan diterapkan secara } \\
\text { konsisten. }\end{array}$ & PJ5 & \\
\hline
\end{tabular}

Sumber: (Ledimo, 2015) 
Tabel 2. Operasionalisasi Variabel Keadilan Distributif

\begin{tabular}{|c|c|c|c|c|}
\hline Variabel & Definisi & Indikator & Kode & Skala \\
\hline \multirow[t]{12}{*}{$\begin{array}{l}\text { Keadilan } \\
\text { Distributif }\end{array}$} & \multirow{12}{*}{$\begin{array}{l}\text { Keadilan distributif } \\
\text { memberikan } \\
\text { perlakuan secara adil } \\
\text { kepada karyawan } \\
\text { yang telah } \\
\text { memberikan } \\
\text { kontribusi terhadap } \\
\text { perusahaan, seberapa } \\
\text { karyawan itu } \\
\text { memberikan } \\
\text { kemampuan } \\
\text { terbaiknya terhadap } \\
\text { perusahaan } \\
\text { tempatnya bekerja } \\
\text { dan menghasilkan } \\
\text { sesuatu yang } \\
\text { bermanfaat. }\end{array}$} & $\begin{array}{l}\text { Misi dan visi organisasi yang } \\
\text { dikomunikasikan secara jelas }\end{array}$ & DJ1 & \multirow[t]{12}{*}{ Ordinal } \\
\hline & & $\begin{array}{lr}\text { Adanya dorongan dari } & \text { untuk } \\
\text { perusahaan strategi } \\
\text { melaksanakan } \\
\text { perusahaan dengan baik }\end{array}$ & $\mathrm{DJ} 2$ & \\
\hline & & $\begin{array}{l}\text { Adanya penerapan peraturan } \\
\text { untuk mendistribusikan } \\
\text { segala aspek keuangan } \\
\text { secara adil. }\end{array}$ & DJ3 & \\
\hline & & $\begin{array}{l}\text { Adanya akses yang sama } \\
\text { dalam penggunakaan } \\
\text { fasilitas perusahaan }\end{array}$ & DJ4 & \\
\hline & & $\begin{array}{l}\text { Bonus diberikan kepada } \\
\text { karyawan berkinerja tinggi } \\
\text { terlepas dari posisi, } \\
\text { departemen, atau tingkat } \\
\text { pekerjaan karyawan. }\end{array}$ & DJ5 & \\
\hline & & $\begin{array}{l}\text { Pemberian rewards } \\
\text { serupapada karyawan yang } \\
\text { memiliki pekerjaan yang } \\
\text { sama }\end{array}$ & DJ6 & \\
\hline & & $\begin{array}{l}\text { Pemberian gaji berdasarkan } \\
\text { pada pekerjaan karyawan }\end{array}$ & DJ7 & \\
\hline & & $\begin{array}{l}\text { Adanya keadaan dimana } \\
\text { semua karyawan terlibat } \\
\text { dalam proses pengambilan } \\
\text { keputusan }\end{array}$ & DJ8 & \\
\hline & & $\begin{array}{l}\text { Karyawan diedukasikan } \\
\text { selama pengembangan } \\
\text { kebijakan baru di perusahaan }\end{array}$ & DJ9 & \\
\hline & & $\begin{array}{l}\text { Kebijakan manajemen } \\
\text { kinerja diterapkan secara } \\
\text { konsisten }\end{array}$ & DJ10 & \\
\hline & & $\begin{array}{l}\text { Karyawan dipromosikan } \\
\text { secara adil }\end{array}$ & DJ11 & \\
\hline & & $\begin{array}{l}\text { Proses rekrutmen dan seleksi } \\
\text { yang dijalankan bersifat adil }\end{array}$ & DJ12 & \\
\hline
\end{tabular}

Sumber: (Ledimo, 2015) 
Tabel 3. Operasionalisasi Variabel Keterikatan Karyawan

\begin{tabular}{|c|c|c|c|c|}
\hline Variabel & Definisi & Indikator & Kode & Skala \\
\hline \multirow[t]{17}{*}{$\begin{array}{l}\text { Keterikatan } \\
\text { Karyawant }\end{array}$} & \multirow{17}{*}{ 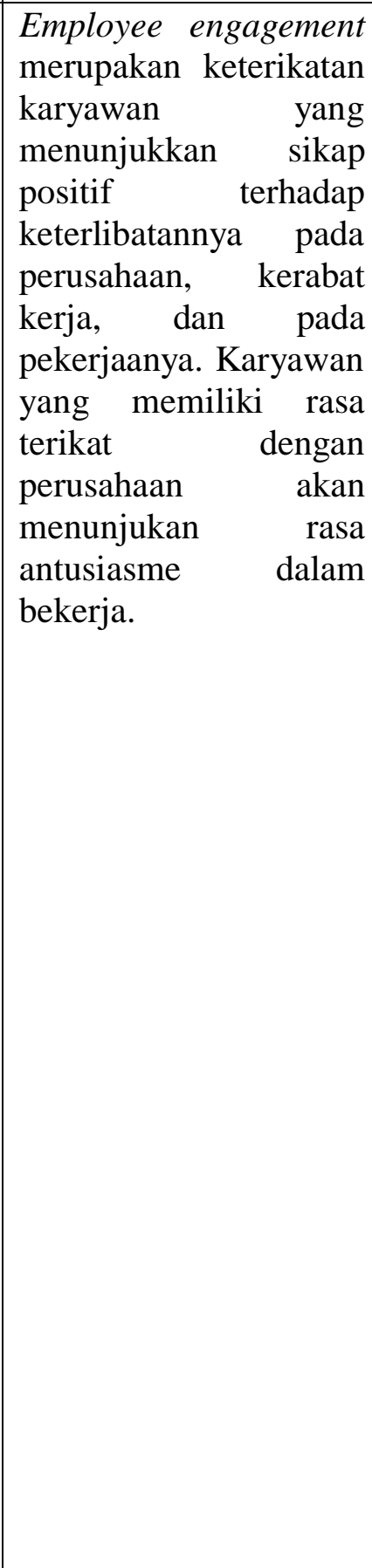 } & $\begin{array}{l}\text { Tempat kerja, merasa } \\
\text { penuh dengan energi }\end{array}$ & EE1 & \multirow[t]{17}{*}{ Ordinal } \\
\hline & & $\begin{array}{l}\text { Pekerjaan yang dilakukan } \\
\text { penuh makna dan tujuan }\end{array}$ & EE2 & \\
\hline & & $\begin{array}{l}\text { Waktu berlalu ketika } \\
\text { bekerja }\end{array}$ & EE3 & \\
\hline & & $\begin{array}{l}\text { Merasa giat dan semangat } \\
\text { ketika bekerja }\end{array}$ & EE4 & \\
\hline & & $\begin{array}{l}\text { Antusias dengan } \\
\text { pekerjaan }\end{array}$ & EE5 & \\
\hline & & $\begin{array}{l}\text { Ketika bekerja, bisa lupa } \\
\text { segala sesuatu yang ada di } \\
\text { sekitar saya }\end{array}$ & EE6 & \\
\hline & & $\begin{array}{l}\text { Pekerjaan yang } \\
\text { menginspirasi }\end{array}$ & EE7 & \\
\hline & & $\begin{array}{l}\text { Ketika bangun di pagi } \\
\text { hari, merasa ingin pergi } \\
\text { bekerja }\end{array}$ & EE8 & \\
\hline & & $\begin{array}{l}\text { Merasa senang ketika } \\
\text { bekerja dengan giat }\end{array}$ & EE9 & \\
\hline & & $\begin{array}{l}\text { Merasa bangga dengan } \\
\text { apa yang dikerjakan di } \\
\text { tempat kerja }\end{array}$ & EE10 & \\
\hline & & $\begin{array}{l}\text { Tenggelam dalam } \\
\text { pekerjaan saya }\end{array}$ & EE11 & \\
\hline & & $\begin{array}{l}\text { Dapat terus bekerja untuk } \\
\text { waktu yang sangat lama }\end{array}$ & EE12 & \\
\hline & & Pekerjaan menantang & EE13 & \\
\hline & & $\begin{array}{l}\text { Menjadi terbawa ketika } \\
\text { bekerja }\end{array}$ & EE14 & \\
\hline & & Bekerja sangat ulet & EE15 & \\
\hline & & $\begin{array}{l}\text { Sulit untuk melepaskan } \\
\text { diri dari pekerjaan }\end{array}$ & EE16 & \\
\hline & & $\begin{array}{l}\text { Dapat bertahan walaupun } \\
\text { keadaan tidak sesuai } \\
\text { harapan }\end{array}$ & EE17 & \\
\hline
\end{tabular}

Sumber: (Schaufeli et al., 2006) 
Tabel 4. Operasionalisasi Variabel Keinginan berpindah

\begin{tabular}{|c|c|c|c|c|}
\hline Variable & Definisi & Indikator & Kode & Skala \\
\hline \multirow[t]{3}{*}{$\begin{array}{l}\text { Keinginan } \\
\text { berpindah }\end{array}$} & $\begin{array}{lr}\text { Turnover } & \text { Intention } \\
\text { ialah niatan } & \text { seorang }\end{array}$ & $\begin{array}{l}\text { Sering berfikir untuk } \\
\text { keluar dari perusahaan }\end{array}$ & TI1 & \multirow[t]{3}{*}{ Ordinal } \\
\hline & $\begin{array}{l}\text { karyawan untuk } \\
\text { meninggalkan } \\
\text { perusahaannya }\end{array}$ & $\begin{array}{l}\text { Mungkin akan mencari } \\
\text { pekerjaan } \\
\text { depan }\end{array}$ & TI2 & \\
\hline & $\begin{array}{l}\text { dikarenakan adanya } \\
\text { rasa ketidaksesuaian di } \\
\text { dalam perusahaannya } \\
\text { dan berniat untuk } \\
\text { mencari pekerjaan } \\
\text { yang lebih baik dalam } \\
\text { jangka waktu tertentu } \\
\text { dan terdapat dampak } \\
\text { negatif turnover } \\
\text { intention bagi } \\
\text { perusahaan yaitu di } \\
\text { butuhkannya } \\
\text { pengeluaran ekstra } \\
\text { untuk merekrut dan } \\
\text { pelatihan karyawan } \\
\text { baru. }\end{array}$ & $\begin{array}{l}\text { Akan aktif } \text { mencari } \\
\text { pekerjaan baru ditahun } \\
\text { depan }\end{array}$ & TI3 & \\
\hline
\end{tabular}

Sumber: (Hielvita, 2016)

\section{HASIL DAN PEMBAHASAN}

\section{Hasil Uji Statistik}

Pengujian validitas data dalam penelitian ini diukur menggunakan nilai validitas konvergen, Average Variance Extracted (AVE) dan validitas diskriminan. Nilai loading factor validitas konvergen harus lebih besar dari 0.7 Jika terdapat nilai loading factor yang kurang dari nilai tersebut harus dieliminasi. Setelah dilakukan running ternyata terdapat beberapa indikator variabel dalam penelitian ini yang nilai loading faktor nya tidak memenuhi syarat, oleh karena itu harus dieliminasi. Indikator indikator tersebut antara lain adalah DJ1, DJ4, DJ7, DJ11 untuk variabel keadilan distributif , indikator EE2, EE4, EE6, dan EE7 untuk indikator keterikatan karyawan. Adapun untuk indikator keadian prosedural dan indikator keinginan berpindah semua memenuhi persyaratan dan tidak ada yang dieliminasii.

Setelah dilakukan eliminasi terhadap indikator indikator tersebut dilakukan running ulang. Gambar 2 berikut adalah hasil perhitungan PLS Algoritm yang menujukkan nilai loading factor setelah beberapa indikator di eliminasi. Dari gambar tersebut dapat diketahui bahwa semua indikator yang menjelaskan variabel dalam penelitian ini telah memenuhi syarat dan valid karena memiliki nilai $>0,7$. 
Gambar 2. Hasil Pengoalahan PLS Algoritm

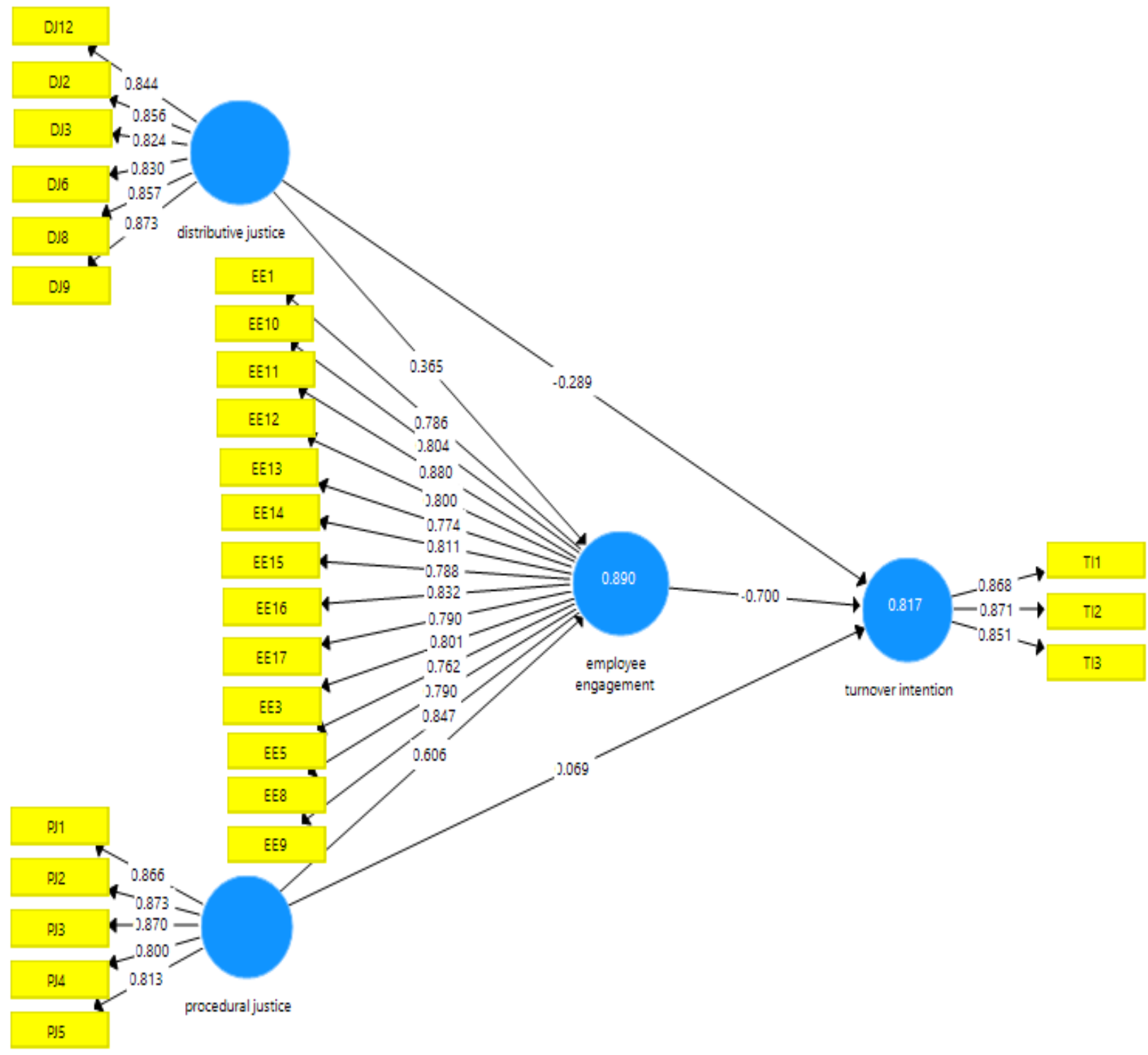

Langkah selanjutnya adalah dengan melakukan pengukuran nilai Average Variance Extracted (AVE) dimana nilai AVE harus lebih besar dari 0,5. Hasil pengolahan data menunjukkan bahwa Nilai AVE untuk setiap variabel ditunjukkan oleh Tabel berikut;

Tabel 5. Hasil Uji Average Variance Extracted (AVE)

\begin{tabular}{l|c}
\hline \multicolumn{1}{c|}{ Variabel } & Average Variance Extracted (AVE) \\
\hline Distributive Justice & 0.718 \\
\hline Employee Engagement & 0.649 \\
\hline Procedural Justice & 0.714 \\
\hline Turnover Intention & 0.745 \\
\hline
\end{tabular}

Sumber: (Hasil Olah data Smar PLS, 2019) 
Dari table 5 diatas diperoleh nilai AVE variabel distributive justice adalah sebesar 0.718, AVE dari variabel employee engagement adalah sebesar 0.649, AVE dari variabel procedural justice adalah 0.714 dan AVE dari variabel turnover intention adalah adalah sebesar 0.745. Jadi dapat disimpulkan bahwa seluruh variabel yang digunakan dalam penelitian ini adalah valid. Berdasarkan hasil pengujian discriminant validity pada tabel 6 , nilai cross loading konstruk yang dituju lebih tinggi daripada cross loading konstruk lain sehingga semua pernyataan pada setiap variabel adalah valid.

Tabel 6. Hasil Pengujian Discriminant Validity

\begin{tabular}{|c|c|c|c|c|}
\hline Indikator & $\begin{array}{c}\text { Distributive } \\
\text { Justice }\end{array}$ & $\begin{array}{c}\text { Employee } \\
\text { Engagement }\end{array}$ & $\begin{array}{l}\text { Procedural } \\
\text { Justice }\end{array}$ & $\begin{array}{l}\text { Turnover } \\
\text { Intention }\end{array}$ \\
\hline DJ12 & 0.844 & 0.691 & 0.717 & -0.666 \\
\hline $\mathrm{DJ} 2$ & 0.856 & 0.751 & 0.737 & -0.754 \\
\hline DJ3 & 0.824 & 0.790 & 0.719 & -0.752 \\
\hline DJ6 & 0.830 & 0.749 & 0.740 & -0.651 \\
\hline DJ8 & 0.857 & 0.799 & 0.785 & -0.755 \\
\hline DJ9 & 0.873 & 0.774 & 0.759 & -0.765 \\
\hline EE1 & 0.777 & 0.786 & 0.737 & -0.727 \\
\hline EE3 & 0.644 & 0.801 & 0.706 & -0.675 \\
\hline EE5 & 0.666 & 0.762 & 0.707 & -0.623 \\
\hline EE8 & 0.737 & 0.790 & 0.742 & -0.748 \\
\hline EE9 & 0.731 & 0.847 & 0.777 & -0.765 \\
\hline EE10 & 0.769 & 0.804 & 0.780 & -0.737 \\
\hline EE11 & 0.781 & 0.880 & 0.796 & -0.801 \\
\hline EE12 & 0.729 & 0.800 & 0.743 & -0.732 \\
\hline EE13 & 0.677 & 0.774 & 0.715 & -0.733 \\
\hline EE14 & 0.776 & 0.811 & 0.750 & -0.674 \\
\hline EE15 & 0.738 & 0.788 & 0.736 & -0.686 \\
\hline EE16 & 0.679 & 0.832 & 0.763 & -0.732 \\
\hline EE17 & 0.679 & 0.790 & 0.747 & -0.728 \\
\hline PJ1 & 0.764 & 0.776 & 0.866 & -0.655 \\
\hline PJ2 & 0.753 & 0.808 & 0.873 & -0.769 \\
\hline $\mathrm{PJ} 3$ & 0.783 & 0.823 & 0.870 & -0.724 \\
\hline PJ4 & 0.701 & 0.731 & 0.800 & -0.726 \\
\hline PJ5 & 0.702 & 0.765 & 0.813 & -0.640 \\
\hline TI1 & -0.761 & -0.765 & -0.726 & 0.868 \\
\hline TI2 & -0.774 & -0.808 & -0.783 & 0.871 \\
\hline TI3 & -0.680 & -0.745 & -0.645 & 0.851 \\
\hline
\end{tabular}

Sumber: (Hasil olah data SmartPLS 3.0, 2019) 
Pengujian reliabilitas data dalam penelitian ini menggunakan cronbach's alpha dan composite reliability. Suatu data dapat dikatakan reliabel jika hasil dari cronbach's alpha> 0.6. Adapun Pengukuran nilai composite reliability harus memiliki nilai 0.7, agar uji reliabilitas dapat diterima, dan hasil pengolahan data menghasilkan nilai cronbach's alpha composite reliability sebagai berikut :

Tabel 7. Hasil Uji Reliabilitas

\begin{tabular}{l|c|c}
\hline \multicolumn{1}{c|}{ Variabel } & Cronbach's Alpha & Composite Reliability \\
\hline Distributive Justice & 0.922 & 0.939 \\
\hline Employee Engagement & 0.955 & 0.960 \\
\hline Procedural Justice & 0.899 & 0.926 \\
\hline Turnover Intention & 0.829 & 0.898 \\
\hline
\end{tabular}

Sumber: (Hasil olah data SmartPLS 3.0, 2019)

Berdasarkan hasil pengujian reliabilitas pada tabel 7, diketahui bahwa semua variabel memiliki nilai cronbach 's alpha diatas 0,6 dan composite realibility di atas 0,7. Dengan nilai tersebut, maka dapat disimpulkan bawa data pada penelitian ini reliabel karena telah memenuhi kriteria.

Setelah pengujian outer model (validitas dan reliabilitas), pengolahan data variabel variabel penelitian dilanjutkan pada tahapan pengujian inner model. Terdapat 3 langkah dalam pengujian inner model meliputi normed fit index, Predictive Relevance $\left(\mathrm{Q}^{2}\right)$, dan Koefisien Determinasi $\left(\mathrm{R}^{2}\right)$.

Nilai $R$ square dari variabel keadilan distributif dan keadilan prosedural terhadap keterikatan karyawan adalah 0.890. Artinya, bahwa variable keterikatan karyawan dikontribusikan sebesar $89 \%$ dari keadailan distributif dan keadilan prosedural, sedangkan sisanya $11 \%$ dipengaruhi oleh variabel lain. Selanjutnya Nilai $R$ square dari variabel keadilan distributif, keadilan prosedural dan keterikatan karyawan terhadap keinginan berpindah adalah 0.817 . Artinya, variabel keinginan berpindah dikontribusikan sebesar 81.7\% oleh keadilan distributif, keadilan prosedural, dan keterikatan karyawan dan sisanya $18.3 \%$ dipengaruhi oleh variabel lain.

Uji Goodness of Fit (GoF) dinilai berdasarkan Normed Fit Index (NFI), NFI menunjukkan angka 0.727 , sudah berada diantara nilai 0 dan 1 , yang artinya telah memenuhi kelayakan model. Berdasarkan hasil Predictive Relevance $\left(\mathrm{Q}^{2}\right)$ dari variabel keadilan disstributif dan keadilan prosedural terhadap keterikatan karyawan adalah sebesar 0.528 (>0) yang berarti nilai-nilai yang diobservasi pada kausalitas direkontruksi dengan baik. Begitujuga dengan Nilai Q Square dari variabel keadi;an distributif, keadilan prosedural dan keterikatan karyawan terhadap keinginan berpindah adalah sebesar $0.558(>0)$ yang membuktikan bahwa nilai-nilai yang diobservasi pada kausalitas ini juga sudah direkonstruksi dengan baik.

Nilai path coefficient digunakan untuk mengetahui hubungan antar variable pada penelitian ini dan tingkat signifikan dalam pengujian hipotesis. Nilai original sampel yang berada diantara -1 sampai dengan +1 diindikasikan sebagai variable yang mempunyai hubungan negatif dampai dengan positif. Pengujian Hipotesis yang dilakukan dalam 
penelitian ini untuk dapat menentukan apakah hipotesis-hipotesis yang telah dibuat dalam penelitian ini mempunyai pengaruh yang siginifikan. Signifikansi hipotesis dilihat dari nilai signifikan $t$-statistik pada algorithm bootstrapping parameter yang harus lebih dari 1.96 dan p-values harus lebih dari 0,05 sehingga terdapat pengaruh yang signifikan terhadap variabel endogen (Ghozali dan Latan, 2015). Gambar 3 berikut menjelaskan hasil pengolahan bootstrapping untuk mengatahui nilai t stastistik dan $p$-values.

\section{Gambar 3. Hasil Uji Bootstrapping}

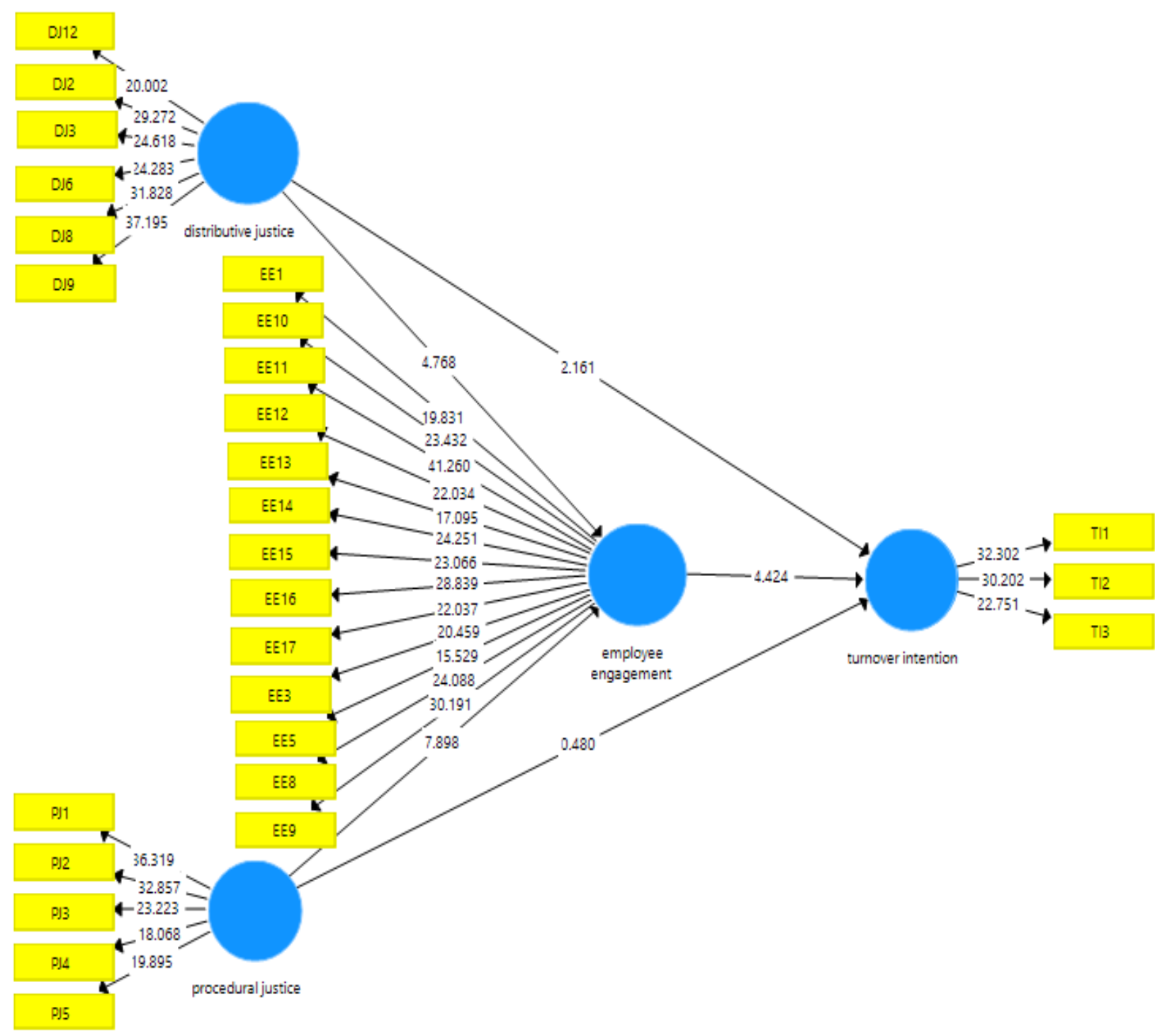

Hasil pengujian untuk hipotesis pertama yang menjelaskan pengaruh keadilan distributif terhadap keterikatan karyawan memberikan nilai original sampel (O) sepebesar 0,365 yang menujukkan terdapat pengaruh positif sedangkan nilai t-statistik yang didapat sebesar $4.786(>1.96)$ dan p-values sebesar $0.000(<0.05)$ yang berarti signifikan. Dapat disimpulkan bahwa terdapat pengaruh positif dan signifikan keadilan distributif terhadap keterikatan karyawan sehingga $\mathrm{H}_{1}$ tidak ditolak. 
Pengujian untuk hipotesis kedua tentang pengaruh keadilan prosedural terhadap keterikatan karyawan diperoleh nilai original sampel $(\mathrm{O})$ sebesar 0,606 yang menunjukkan terdapat pengaruh positif keadilan prosedural terhadap keterikatan karyawan. Nilai tstatistik yang didapatkan adalah sebesar 7,986 (>1.96) dan p-values $(0,000)$ yang berarti signifikan jadi dapat disimpulkan bahwa terdapat penagruh posisitif dan signifikan keadilan prosedural terhadap keterikatan karyawan sehingga $\mathrm{H}_{2}$ tidak ditolak.

Pada hipotesis ketiga untuk melihat pengaruh keadilan distributif terhadap keinginan berpindah diperoleh nilai original $(\mathrm{O})$ sampel sebesar -0,289 yang menunjukkan terdapat pengaruh negatif keadilan distributif terhadap keinginan berpindah. Dengan nilai t-statistik $2,161(>1,96)$ dan p- values $0,031(<0,05)$ menunjukan bahwa terdapat pengaruh negatif dan signifikan keadilan distributif terhadap keinginan berpindah sehingga $\mathrm{H}_{3}$ tidak ditolak

Hipotesis keempat bertujuan untuk mengetahui pengaruh keadilan prosedural terhadap keinginan berpindah. Nilai original sampel (O) yang didapat adalah 0,069. Dengan nilai t-statistik sebesar $0,480(<1,96)$ dan $\mathrm{p}$ values $0,6319>0,05)$ menunjukkan bahwa pengaruh keadilan prosedural terhadap keinginan berpindah tidaklah siginifikan sehingga $\mathrm{H}_{4}$ ditolak.

Peran variabel mediasi keterikatan karyawan dapat diketahui jika kita melakukan uji mediasi masing masing pada hipotetsis kelima dan hipotesis keenam. Hasil pengujian untuk hipotesis kelima (keadilan distributif terhadap keinginan berpindah dengan keterikatan karyawan sebagai mediator) memiliki nilai original sample $(\mathrm{O})$ direct effect sebesar -0,289 sedangkan nilai original sample (O) indirect effect adalah sebesar -0,256 hal ini menunjukkan adanya penurunan nilai original sample setelah terdapat variabel keterikatan karyawan sebagai mediasi. Nilai t-statistik yang didapat sebesar 3,683 $(>1,96)$ dan $p$-values sebesar $0.000(<0.05)$ yang berarti signifikan. Nilai $p$-value direct effect sebelumnya adalah 0.031 sedangkan $p$-value indirect effect 0.000 menunjukkan adanya efek partial control dan dapat disimpulkan bahwa keadilan distributif berpengaruh negatif dan signifikan terhadap keinginan berpindah dengan keterikatan karyawan sebagai mediasi, artinya $\mathrm{H}_{5}$ tidak ditolak.

Efek mediasi selanjutnya yang akan dilihat adalah apakah keterikatan karyawan mampu memediasi pengaruh keadilan prosedural terhadap keinginan berpindah (hipotesis keenam). Nilai original sample $(\mathrm{O})$ direct effect yang telah dihitung sebelumnya adalah sebesar 0,069 dengan nilai t-statistik 0,480 $(<1,96)$ dan $p$ value $0,631(>0,05)$ dan tidak signifikan, sedangkan nilai original sample $(\mathrm{O})$ indirect effect adalah sebesar $-0,425$ dengan nilai t-statistik yang didapat sebesar 3,543 $(>1,96)$ dan $p$-values sebesar $0.000(<0.05)$ yang berarti signifikan. Hasil pengujian ini menyimpulkan bahwa variabel keterikatan karyawan ternyata mampu menjadi full mediator pangaruh keadilan prosedural terhadap keinginan berpindah dan artinya $\mathrm{H}_{6}$ tidak ditolak.

Uji hipotesis ketujuh ditujukan untuk mengetahui pengaruh keterikatan karyawan terhadap keinginan berpindah. Nilai original sample $(\mathrm{O})$ yang didapatkan adalah sebesar 0,700 yang menunjukkan terdapat pengaruh negatif keterikatan karyawan terhadap keinginan berpindah. Dengan nilai t-statsistik sebesar 4,242 $(>1,96)$ dan $p$ values sebesar $0,000(<0,05)$ dapat disimpulkan bahwa terdapat pengaruh negatif dan sinifikan variabel keterikatan karyawan terhadap keinginan berpindah, sehingga $\mathrm{H} 7$ tidak ditolak. Untuk lebih jelasnya hasil pengujian hipotesis dirangkum dalam tabel 8 berikut. 
Tabel 8. Hasil Uji Hipotesis

\begin{tabular}{c|l|c|c|c|c}
\hline Hipotesis & Pengaruh Variabel & $\begin{array}{c}\text { Orginal } \\
\text { sampel } \\
(\boldsymbol{O})\end{array}$ & $\begin{array}{c}\text { T Statistic } \\
(|\mathbf{O} / \mathbf{S T D E V}|)\end{array}$ & $\begin{array}{c}\boldsymbol{P} \\
\text { Values }\end{array}$ & Kesimpulan \\
\hline H1 & $\begin{array}{l}\text { Keadilan distributif } \rightarrow \\
\text { Keterikatan karyawan }\end{array}$ & 0.365 & 4.786 & 0.000 & $\begin{array}{c}\text { tidak } \\
\text { ditolak }\end{array}$ \\
\hline H2 & $\begin{array}{l}\text { Keadilan prosedural } \rightarrow \\
\text { Keterikatan karyawan }\end{array}$ & 0.606 & 7.896 & 0.000 & $\begin{array}{c}\text { tidak } \\
\text { ditolak }\end{array}$ \\
\hline H3 & $\begin{array}{l}\text { Keadailan distributive } \\
\text { Keinginan berpindah }\end{array}$ & -0.289 & 2.161 & 0.031 & $\begin{array}{c}\text { tidak } \\
\text { ditolak }\end{array}$ \\
\hline H4 & $\begin{array}{l}\text { Keadilan prosedural } \rightarrow \\
\text { Keinginan berpindah }\end{array}$ & 0.069 & 0.480 & 0.631 & ditolak \\
\hline H5 & $\begin{array}{l}\text { Keadilan distributif } \rightarrow \\
\text { Keterikatan karyawan } \\
\text { Keinginan berpindah }\end{array}$ & -0.256 & 3.682 & 0.000 & $\begin{array}{c}\text { tidak } \\
\text { ditolak }\end{array}$ \\
\hline H6 & $\begin{array}{l}\text { Keadilan prosedural } \rightarrow \\
\text { Keterikatan karyawan } \\
\text { Keinginan berpindah }\end{array}$ & -0.425 & 3.543 & 0.000 & $\begin{array}{c}\text { tidak } \\
\text { ditolak }\end{array}$ \\
\hline H7 & $\begin{array}{l}\text { Keterikatan karyawan } \rightarrow \\
\text { Keinginan berpindah }\end{array}$ & -0.700 & 4.242 & 0.000 & $\begin{array}{c}\text { tidak } \\
\text { ditolak }\end{array}$ \\
\hline
\end{tabular}

Sumber: (Diolah dari SmartPLS, 2019)

\section{DISKUSI}

Hasil analisis data yang telah dilakukan pada penelitian ini menunjukkan bahwa terdapat pengaruh positif keadilan distributif dan keadilan porosedural terhadap keterikatan karyawan. Artinya apabila keadilan distributif dan keadilan prosedural dalam suatu perusahaan semakin baik maka keterikatan karyawan terhadap perusahaan akan semakin meningkat, sehingga kecil kemungkinan untuk keluar dari perusahaan. Hasil penelitian ini sejalan dengan penelitian yang dilakukan oleh (Hongwei et al., 2013), (Özer et al., 2017), dan (Al-Shbiel et al., 2018). Penelitian ini juga menemukan bahwa keadilan distributif mempunyai pengaruh negatif terhadap keinginan berpindah, artinya keinginan karyawan untuk keluar atau pindah ke perusahaan lain akan semakin menurun jika mereka mendapat keadilan distributif. Hal ini sesuai dengan hasil penelitian yang dilaporkan oleh (Al-Shbiel et al., 2018); (Sadia, 2018); (Raza et al., 2017) dan (Özer et al., 2017). Namun hasil ini berbeda dengan peneitian yang dilakukukan oleh (Court et al., 2018) yang manyatakan bahwa keadilan distributif tidak mempunyai pengaruh signifikan terdahap keinginan berpindah. Penemuan lainnya dari penelitian ini adalah bahwa tidak terdapat pengaruh signifikan keadilan prosedural terhadap keinginan berpindah. Hasil ini sejalan dengan penelitian dari (Mohd et al., 2013).

Pengaruh keadilan prosedural terhadap keinginan berpindah ternyata menjadi signifikan apabila ditambahkan variabel mediasi yaitu keterikatan karyawan. Dalam hal ini keterikatan karyawan berperan sebagai full mediator, adapun pada pengaruh variabel keadilan distributif terhadap keinginan berpindah keterikatan karyawan hanya sebagai 
partial mediator. Hasil penelitian sejalan dengan penelitian yang dilakukan oleh (Al-Shbiel et al., 2018), (Özer et al., 2017), dimana keterikatan karyawan mampu memediasi pengaruh keadilan distributif terhadap keinginan berpindah.

Pengaruh keterikatan karyawan terhadap keinginan berpindah pada penelitian ini menemukan bahwa terdapat pengaruh signifikan negatif. Ini menunjukkan bahwa semakin tinggi tingkat keterikatan karyawan terhadap perusahaan akan semakin kecil keinginan untuk berpindah. Hasil ini sejalan dengan penelitian yang dilakukan oleh (Agoi, 2015), (Manish dan Musarrat, 2017) dan (Meydy, 2018)

\section{KESIMPULAN}

Penelitian ini menyimpulkan bahwa keadilan distributif dan keadilan prosedural menjadi faktor yang berpengaruh terhadap keterikatan karyawan. Hal ini mengharuskan perusahaan untuk selalu melakukan perbaikan terhadap keadilan distributif dan kedilan prosedural agar karyawan merasa betah dan tetap berada sebagai bagian yang tidak terpisahkan dalam perusahaan. Pemberian edukasi kepada karyawan jika terdapat pengembangan dan kebijakan baru di perusahaan seharusnya dipertahankan. Penerapan peraturan untuk mendistribusikan segala aspek keuangan secara adil harus menjadi perhatian utama pada PT.XYZ untuk perbaikan keadilan distributif. Pemberian gaji yang adil untuk karyawan yang dipekerjaan pada posisi yang sama adalah hal lain yang juga harus diperhatikan untuk perbaikan keadilan prosedural. Karyawan yang telah memiliki akses yang sama ke program kesehatan hendaknya tetap dipertahankan. Penugasan karyawan dengan pemberian kerja yang lebih menantang dan sesuai dengan tugas pokok dan fungsi akan dapat membuat keterikatan karyawan akan semakin meningkat terhadap perusahaan.

Penelitian lanjutan dengan menggunakan variabel lain yang berpengaruh terhadap keinginan berpindah misalnya stress kerja, kepuasan kerja ataupun budaya organisasi mungkin akan memberikan hasil yang berbeda apalagi jika dilakukan pada industri yang berbeda pula, dengan menggunakan sampel yang lebih banyak dan metodologi yang berbeda dengan penelitian ini.

\section{DAFTAR PUSTAKA}

Agoi, Loice Faith. (2015). Effect of Work Engagement on Employee Turnover Intention in Public Sector, Kenya. International Journal of Economics, Commerce and Management. Vol. 3, Issue 12.

Alotaibi, G. A. (2001). Antecedents of Organizational Citizenship Behavior: A Study of Public Personal in Kuwait. Public Personal Management. 3, 30, 36.

Al-Shbiel, Seif Obeid., Muhannad Akram Ahmad, Awn Metlib Al-Shbail, Hamzah AlMawali, Mohannad Obeid Al-Shbail (2018). The Mediating Role of Work Engagement in the Relationship between Organizational Justice and Junior Accountants' Turnover intentions. Academy of Accounting and Financial Studies Journal. Volume 22, Number 1.

Budiarto, Yohanes dan Wardani, Rani Puspita. (2005). Peran Keadilan Distributif, Keadilan Prosedural Dan Keadilan Interaksional Perusahaan Terhadap Komitmen Karyawan Pada Perusahaan. Fakultas Psikologi Universitas Tarumanagara. Jakarta. Jurnal Psikologi. Vol 3, No.2. 
Bothma, F. Chris dan Gert Roodt. (2012). Work-based Identitiy and Work Engagement as Potential Actecedants of Task Performance and Turnover Intention: Unravelling a Complex Relationship. Journal of Industrial Psychology. Vol 38, No 1, 1-17.

Calton, Jenna and Cattaneo, Lauren Bennett. (2014) The Effects of Procedural and Distributive Justice on Intimate Partner Violence Victims' Mental Health and Likelihood of Future Help-Seeking. American Journal of Orthopsychiatry. Vol 84, No 4.

Chi, N.W dan Han T.S. (2008). Exploring the Linkages Between Formal Ownership And Psychological Ownership for the Organization: The Mediating Role of Organizational Justice”. Journal of Occupational and Organizational Psychology. Vol 81, Issue 4.

Cendani, Citta, dan Tjahjaningsih, Endang (2015). Pengaruh Employee Engagement dan Modal Sosial terhadap Kinerja Karyawan dengan OCB (Organizational Citizenship Behaviour) sebagai Mediasi (Studi pada Bank Jateng Kantor Pusat). Media Ekonomi dan Manajemen. Vol. 30 No. 2.

Colquitt, Jason A, Jeffery A. Lepine, M.J. Wesson. (2015). Organizational Behavior: Improving Performance and Commitment. 4th Edition. McGraw-Hill Education.

Court Ogele Timinepere., Emmanuel K. Agbaeze, Ann Ogbo Nwadukwe Uche C, (2018). Organizational Justice and Turnover Intention among Medical and Non-Medical Workers in University Teaching Hospitals. Journal of Social Sciences, Vol 9 No 2.

Dharma, Cipta. (2013). "Hubungan Antara Turnover Intention Dengan Komitmen Organisasional di PT. X Medan”. Jurnal Ekonomi dan Bisnis Jurusan Administrasi Niaga Politeknik Negeri Medan. Volume 1 No. 2.

Dematria, Pringgabayu dan Hendriady D. Keizer. (2017). Penerapan Sistem Rekrutmen Untuk Meningkatkan Keterikatan Karyawan. Jurnal Manajemen Maranatha. Volume 16, Nomor 2.

Dewi, K. Ayu Budiastiti Purnama dan Wibawa, I Made Artha. (2016). Pengaruh Stres Kerja Pada Turnover Intention Yang Dimediasi Kepuasan Kerja Agen AJB Bumiputera 1912. E-Jurnal Manajemen Unud. Vol. 5, No. 2.

Fong, Y.L and Matsura Mafhar. (2013). Relationship between Occupational Stress and Turnover Intention among Employees in a Future Manufacturing Company in Selangor. Jurnal Teknologi (Social Sciences). Vol 64, No 1, 33-39.

Garson, G. D. (2016). Partial Least Square: Regression \& Structural Equation Models. USA: Statistical Associates Blue Book Series.

Ghozali, I. dan Latan, H. (2015). Konsep, Teknik, Aplikasi Menggunakan Smart PLS 3.0 Untuk Penelitian Empiris. BP Undip. Semarang.

Greenberg, J. and Baron Robert A. (2007). Behavior in Organization. (9th Edition). Prentice Hall.

Hair, J. F., Ringle, C. M., and Sarstedt, M. (2011). PLS-SEM: Indeed a Silver Bullet. The Journal of Marketing Theory and Practice, 19(2), 139-151.

Harhara, Alif. Saif, Sanjay Kumar Singh, Matloub Hussain, (2015). Correlates of employee turnover intentions in oil and gas industry in the UAE. International Journal of Organizational Analysis. Vol 23, No 3.

Harter, James. K., Frank L. Schmidt, Theodore L. Hayes (2002). Busines-Unit-Level relationship between employee statisfaction, employee engagement, and business outcomes: A meta-analysis. Journal of Applied Psychology, Vol 87, No 2. 
Hielvita Ludiya. (2016). Pengaruh Work Life Polices, Work Life Conflict, Job Stress, dan Loneliness Terhadap Turnover Intentions pada Sebuah Universitas Swasta di Kota Batam. Jurnal Manajemen dan Pemasaran Jasa. Vol 9 no 2.

Hongwei He., Weichun Zhu, Xiaoming Zheng, (2013). Procedural Justice and Employee Engagement: Roles of Organizational Identification and Moral Identity Centrality. Journal of Business Ethics. Vol 122, No 4.

Hussein, A. S., (2015). Penelitian Bisnis dan Manajemen Menggunakan Partial Least Square (PLS) dengan SmartPLS 3.0. Universitas Brawijaya.

Kardiman, RR. Dian dan Indriana T.L. (2012). Pengaruh Budaya Organisasi, Komitmen Organisasi, dan Kepuasan Kerja terhadap Turnover Intention Karyawan (Studi Kasus Pada PT Nyonya Mener Semarang). Juraksi. Vol 1, No 1.

Kreitner, Robert and Kinicki, Angelo. (2013). Perilaku Organisasi (Orgaizational Behavior). Edisi 9. Jakarta: Salemba Empat.

Ledimo, Ophillia. (2015). Development and Validation of an Organisational Justice Measurement Instrument for a South African Context. Journal Financial Markets \& Institutions. Vol 5, Issue 1.

Lee, Kyootai. Monica Sharif, Terri Scandura, Jongweon Kim. (2017). Procedural Justice as a Moderator of the Relationship between Organizational Change Intensity and Commitment to Organizational Change, Journal of Organizational Change Management, Vol. 30 Issue: 4.

Lewis, R. Philipus. (2013). Keadilan Distributif, Keadilan Prosedural, Keadilan Interaksional Kompensasi dan Komitmen Karyawan. JRMB. Volume 8, No.1.

Manish Gupta and Musarrat Shaheen, (2017) Impact of Work Engagement On Turnover Intention: Moderation By Psychological Capital In India. Journal of Business. Vol 18, No1, 136-143.

MacLeod, David and Nita Clarke. (2009) Engaging for Success: Enhancing Performance through Employee Engagement. A report to Government. London: Department for Business, Innovation and Skills.

Meydy Fauziridwan. (2018), Pengaruh Employee Engagement dan Kepuasan Kerja Terhadap Organizational Citizenship Behavior (OCB) Serta Dampaknya Terhadap Turnover Intention. Jurnal Ekonomi, Bisnis, dan Akuntansi (JEBA). Vol 20, No 01.

Mohd Remie Bin Mohd Johan., Mohamed Syazwan Bin Ab Talib, Tebogo Martha Joseph, Tshegofatso Lesego Mooketsag. (2013). Procedural and Distributive Justice on Turnover Intention: An Exploratory Analysis. Journal of Contemporary Research in Busines. Vol 4, No 9.

Murfat Effendi. (2018). Pengembangan Model Kepuasan Kerja Untuk Menghadapi Turnover Intention Karyawan Pada PT Kitadin Site Embalut (Kalimantan Timur). Research Journal of Accounting and Business Management (RJABM). Vol 2 No 2.

Mustika, Silvia Indra dan Kusdi Rahardjo. (2017). Pengaruh Perceived Organizational Support Terhadap Employee Engagement dan Organizational Citizenship Behaviour (Studi pada Staf Medis Rumah Sakit Lavalette Malang). Jurnal Administrasi Bisnis. Vol. 47 No.1.

Özer, Özlem, Özgür Uğurluoğlu", Meltem Saygıl1. (2107). Effect of Organizational Justice on Work Engagement in Healthcare Sector of Turkey. Journal of Health Management. Vol 19, No 1, 1-11. 
Rarasanti, Ida Ayu Putri dan Suana, I Wayan. (2016). Pengaruh Job Embeddedness, Kepuasan Kerja, dan Komitmen Organisasional Terhadap Turnover Intention Karyawan. E-Jurnal Manajemen Universitas Udayana. Vol. 5, No.7.

Raza, Muhammad Ali, Amir Gulzar, Rubina Jabeen. (2017). Impact of Distributive Justice on Trust in Leader and Employee Turnover Intention: Moderating Role of Islamic Work Ethics and Organizational Culture. Journal of Islamic Business and Management. Vol 7, No 2, 248-265.

Robbins, Stephen P dan Judge, Timothy A. (2015). Perilaku Organisasi. Edisi 16. Jakarta: Salemba Empat.

Ronald Sukwadi dan Milkha Meliana. (2014). Faktor-Faktor yang Mempengaruhi Kinerja dan Turnover Intention Karyawan Usaha Kecil Menengah. Jurnal Rekayasa Sistem Industri. Vol 3, No 1.

Sadia Arif. (2018). Impact of Organizational Justice on Turnover Intentions: Moderating role of Job Embededdness. Journal of Management. Vol. 1. Issue 2.

Saeka, I Putu Agus Pande dan I Wayan Suana. (2016). Pengaruh Kepuasan Kerja, Komitmen Organisasional dan Stres Kerja Terhadap Turnover Intention Karyawan PT. Indonusa Algaemas Prima Bali. E-Jurnal Manajemen Unud, Vol. 5, No. 6.

Schaufeli, Wilmar, B. Arnold B. Bakker, Marisa Salanova. (2006). The Measurement of Work Engagement With a Short Questionnaire. Journal of Educational and Psychology Measurement. Vol 66, No 4.

Schaufeli, W.B., and Bakker, Arnold B.. (2004). Job Demands, Job Resources, and Their Relationship With Burnout and Engagement: A multi-sample study. Journal of Organisational Behavior. Vol. 25, 293-315.

Sekaran, U. and Bougie, R. (2016). Research Methods for Business (6 ${ }^{\text {th }}$ ed). Southern Gate, Chichester, West Sussex: John Wiley \& Sons, Ltd.

Selfiana. (2016). Budaya Organisasi Mempengaruhi Employee Engagement Di Perusahaan Kontraktor Telekomunikasi Alihan Perusahaan Jepang. Jurnal Administrasi Kantor, Vol 4, No 2.

She Hwei T dan Santosa Elisabeth Cintya. (2012). Pengaruh Keadilan Prosedural dan Keadilan Distributif Terhadap Komitmen Organisasi. Jurnal Dinamika Ekonomi \& Bisnis. Vol. 9 No. 2.

Tjahjono, Heru K., Palupi, M, Nuri, Rafika. (2014). "Pengaruh Keadilan Distributif Karir dan Keadilan Prosedural Karir terhadap Perilaku Retalisasi Karyawan Swasta di Daerah Istimewa Yogyakarta dengan Kepuasan Karir sebagai Variabel Pemediasian”. Jurnal Universitas Paramadina. Vol. 11 No. 2.

Vera Susiani. (2014). Pengaruh Kepuasan Kerja dan Komitmen Organisasi pada Turnover Intention. E-Jurnal Manajemen Universitas Udayana. Vol 3, No. 9. 